\title{
LIVELIHOODS STATUS OF RURAL WOMEN ENTREPRENEURS WITH SPECIAL REFERENCE TO SELF HELP GROUPS IN KEERAPALAYAM BLOCK, CUDDALORE DISTRICT
}

\author{
Dr. R. Babybowna \\ Assistant Professor, Department of Economics, Government \\ Arts College, C.Mutlur, Chidambaram
}

\begin{abstract}
The most important social innovation to help the poor in recent years has been the success of the thrift and credit based self help groups (SHG), especially those formed by women. These groups assisted by NGOs have successfully developed a system of revolving credit for the benefit of group members based on their own savings. SHGs have successfully maintained in high rate if loan repayments and successfully generated additional income, jobs, and small enterprises for their members. The first national conference of women entrepreneurs held at New Delhi in November 1981 advocated the need for developing women entrepreneurs for the overall development of the country. It called for priority to women in allotment of Land. Sanction of power, Licensing etc... the second international conference of women entrepreneurs organized by the National Alliance of young entrepreneurs (NAYE) held in 1989 at New Delhi. Entrepreneurship development among women can be considered a possible approach to economic empowerment of women. Human resources and technology are the two important factors of growth in new economic order. To activate these two factors like livelihoods and require rural entrepreneurship development in a big way in an economy. Women's entrepreneurship has become an important aspect of the changed Indian economic. The participation of women in different innovative business undertakings has empowered them in the social, economic and cultural arena specifically, economists, social workers and social scientists have studied rural women and entrepreneurship in India at various levels
\end{abstract}

KEYWORDS: SHGs, NGOs, income, jobs, small enterprises, women Entrepreneurs, social workers, social scientists

\section{INTRODURTION}

Self Help Groups are engaged in and facilitate, the maximum use of human resources, efficient utilization of local natural resources, promotion of rural economy helping weather sections, enhancing saving habits increasing (self) employing opportunities, instilling self confidence and self reliance, empowerment of women and causing overall economic development of the country including rural economy. The main objectives of SHGs are thus to develop leadership quality, self confidence and reliance, increase social' awareness, improve status of women in family and society, improve health and family welfare, 
functional literacy, increase income assets include the habit of savings and no develop economy. Self help groups undertake entrepreneurial activities as smaller level with minimum capital requirements. In future, the inbuilt strength of the self help groups will pave the way to undertake mega projects, like projects. Performed by join stock companies, public sectors enterprises etc. self help groups have made the: rural women to contribute for the socio economic progress of the country.

The concept of self - help group (SHG) is a silent revolution in the rural credit delivery systems in many parts of the would. The basic principles of which self help groups function are approach mutual trust organization of poor, manageable small group, cohesiveness, demand based lending, women friendly loan, skill training capacity building and empowerment. Identical Interest, Small size, Transparency L"1 operations, Common fund contributors, Flexibility and responsiveness, Democratic functioning, Simple documentation, Terms of credit decided in the group, Minimum external intervention, Repayment by dynamics, Causal group solidarity. SHGs are a group of rural poor who have volunteered to organize themselves into groups for eradication of poverty of the members. SHGs have the potential to remedy the ills of formal basking system is rural areas and to empower women economically and socially by acting as a bridge between women living poverty.

Women's participation plays a significant role in rural employment activities. The self would concentrate on all round development of the beneficiaries and their village as a whole. The groups would undertake the responsibility of delivering nom-credit services such as literacy, health and environmental issues. The concept of self group would mould women as responsible citizens of the country for achieving and economic status. Mahalir Thittam aims to achieve four key aspects to empower rural women, especially those living below the poverty line - economic, social, educational and political among this economic empowerment was the crucial as it would bring about the other three aspects. The five year entrepreneurship development programme trains SHGs to be self-sufficient and resourceful in running their business. SHGs are a media for the development of saving habits among the women fold. It mobilizes a large quantum of resources. It is a window for better technology and skill up gradation. It helps to increase an income of the family. In SHGs collective and solidarity are important empowering mechanism.

Women entrepreneurship has been recognized as an important source of economic growth as they create new jobs for themselves and also provide society with different solutions to management, organization and business. Women's entrepreneurship contributes to the economic well-being of the families, communities and reduces poverty. Entrepreneurs have been considered instrumental in initiating and sustaining socio-economic development. In recent years entrepreneurship has gained ground both in theoretical circles and policy implementations of central authorities. Modernization has meant that there is an expansion of networking and information technology within society, along with innovation due to entrepreneurship. This is vital for local, regional and national development (Lash, 1994; Sweeney, 1987). Women's entrepreneurship has become an important aspect of the changed 
Indian economic climate (Tiwari, 2007, p11). The participation of women in different innovative business undertakings has empowered them in the social, economic and cultural arena (Nawaz, 2009, p1). Specifically, economists, social workers and social scientists have studied rural women and entrepreneurship in India at various levels.

\section{REVIEW OF LITERATURE}

Lalitha Shivakumar (2018) Pointed out that the small savings by rural women can generate the required resources which can wean the people away from the exploitation of money lenders Savings depend on habits and voluntary savings constitute the key for economic progress. It has also been proved that poor people can save substantially through group efforts. Promotion of self-help groups has the potential to bring women into the mainstream of economic development paving the way for sustainable development.

Gurumoorthy (2018) pointed out that "The outreach of self help groups can become an important link for formal credit institutions as an entry point. The loan recovery of the SHG depends on social peer pressure and bankers can learn a few lessons in recovery from the SHGs.

Sivasubramainan (2017) in his study had also stressed the "Elimination of poverty is one of the principle objectives of Indian development strategy. In 1993, the below poverty line was 36 percent. The data was available which worked out to 320 million people of whom 224 million line in rural areas. The incident of poverty had declined from 54.9\% in 1973-74 to $36 \%$ in 1993-94. The salient features of anti-poverty programmes are framed under various schemes to bring growth. The reformed scheme of Swarna Jayanthi Gram Swarozger Yojana (SGSY) would be centered on the concept of SHGs and cluster approach for reaching out the poor as effective vehicle poverty can be attentively eradicated only when the poor start contributing to the growth process through a process of social mobilization and participatory approach and empowerment of the poor.

Dwarki and Kumaesen (2016) suggested that in the heart of the SHG approach there is nothing new for the Indian rural community where some people are coming together to pool their resources for the betterment of the needy. This approach was maintained the motto to help the villager to help themselves. One should realize with it the potentiality of severing the negative factors in the process of rural development. Although the SHG approach promotes participation among people to a noticeable degree, development of capacity building towards self sustenance and ultimate withdrawal of the change agent do not seem to be many where in sight. The NGOs and institutions are only maintaining self help group as independent based discrete duties, but to promote development action from outside the village which is the direction of adieu.

Pater (2016) regarded that the announcement of National Agricultural policy recently by the Government if India and signing the Agreement on Agriculture with the world Trade Organization demands a focused attention need to be given to restructure the Rural credit 
system along with integrating agricultural restructure the Rural credit system, building rural infrastructure and making Government officials responsive to the emerging needs of farm sector development. It is against this background an attempt is made here to appreciate the present status of the rural credit structure in respect of credit disbursal, recovery performance and building up of non - performing assets, declining trend in the flow of credit and other issues of serious concern.

Ghoosh (2015) pointed out that there is no doubt that combating poverty cannot be managed by the government alone. There are many areas where government needs collaboration and co-operation from NGOs particularly in creating opportunity facilitating empowerment and providing security to the poor. The pressure of the donor agencies on the recipient government to work through NGOs in development programme is als0 dominant factor in increasing the role NGOs to against poverty.

Jaya Anand (2015) in his work entitled Micro Finance in Kerala has explained that the society model proved to be effective to be effective way of eradicating poverty through participatory and transport process. The micro credit finance supported micro - enterprise to end poverty by determining assured opportunity in marketing, skill up gradation and technical training.

\section{RESEARCH METHODOLOGY}

\section{Objectives of the study}

* To study the impact of socio-economic factors on the entrepreneurial activities of rural women entrepreneurs of self help groups.

- To highlight the factors enabling rural women to become entrepreneurs through self help groups.

\section{Hypotheses}

There may be relationship between income and occupation.

\section{Research Design}

\section{Sampling Technique}

The Sample for on in self groups are selected by random sampling technique was embraced in the present investigation to choose the example respondents. It is a technique in which a total rundown of the populace is accessible from five villages where tests are to be drawn

\section{Sample size}

Cuddalore District having 13 blocks, among the blocks Keerapalayam is one of the blocks which have shown a better performance in rural women entrepreneurs to self help groups. The study is bases on primary dada. The required dada are collected with the help of detailed schedule by the direct interview method. Sample for on in self groups are selected by random sampling from the selected five village viz. (Thennalakudi, Karaimedu, Annanperumal Kovil, Karukudi and Thiruvali). The Secondary data are collected from journals, magazine, published and unpublished materials. 


\section{Data Analysis}

The collected data are classified and tabulated with the help of computer programming. Cross tabulation is made for data pertaining to socio-economic background of the respondents. The percentage and average are extensively applied in the study to discuss field data.

\section{ANALYSIS AND DISCUSSION}

Table 4.1 Age wise distribution of the respondent

\begin{tabular}{|c|l|c|}
\hline S.No. & \multicolumn{1}{|c|}{ Age group } & No. of Respondents \\
\hline 1. & $20-25$ & 20 \\
\hline 2. & $26-30$ & 40 \\
\hline 3. & $31-35$ & 30 \\
\hline 4. & Above 36 & 10 \\
\hline & \multicolumn{2}{|r|}{ Total } \\
\hline
\end{tabular}

Source: Computed

From the above table (4.1) shows that distribution of respondents according to their age. There are 100 respondents interviewed of which 20 respondents belongs to the age group of 20-25; 40 respondents are belongs to the age group of 26-30 category; Another 30 members are belongs to the age group of 31-35 category; only 10 members ate belongs to the age group of above 36 respectively. It is found that, majority of them ate (40\%) belongs to the age group of 26-30 category followed by (30\%) in the age group of $31-35 ; 20$ percent in the age group of $20-25$ and 10 percent of the age group of above 36 age group.

Table 4.2 Community wise distribution of the respondents

\begin{tabular}{|c|c|c|}
\hline S.No. & Caste & No. of Respondents \\
\hline 1 & Scheduled Caste & 50 \\
\hline 2 & Most Backward caste & 23 \\
\hline 3 & Backward caste & 27 \\
\hline & Total & 100 \\
\hline
\end{tabular}

Source: Computed

The table No. 4.2 shows that the community wise distribution of the respondents. 50 respondents are Scheduled Casts, 23 respondents are most backward caste and 27 respondents are Backward Caste. It is noticed that, 50 percent of them are belongs to the scheduled caste are higher in number than other caste people.

Table 4.3 Marital status wise distribution of the respondents

\begin{tabular}{|c|l|c|}
\hline S.No & Family Structure & No. of Respondents \\
\hline 1 & Married & 83 \\
\hline 2 & Unmarried & 17 \\
\hline 3 & Others & 0 \\
\hline & \multicolumn{2}{|r|}{ Total } \\
\hline
\end{tabular}

Source: Computed 
The table no. 4.3 shows that the Marital status of the respondents. It is clear that the 83 respondents are married and 17 respondents are unmarried.

Table 4.4 Type of Family wise distribution of the respondents

\begin{tabular}{|c|l|c|}
\hline S.No & \multicolumn{1}{|c|}{ Category } & No. of Respondents \\
\hline 1 & Nuclear Family & 65 \\
\hline 2 & Joint Family & 35 \\
\hline & Total & $\mathbf{1 0 0}$ \\
\hline
\end{tabular}

Source: Computed

Out of the 100 respondents 65 respondents are living as nuclear families and 35 respondents are living as joint families. The reason for the larger numbers of women entrepreneurs to come from nuclear families is because these type of families have more leisure time and they are free to make plans and take decision on their own.

Table 4.5 Educational Qualification wise distribution of the Respondents

\begin{tabular}{|l|l|c|}
\hline S.No. & Educational Qualification & No. of Respondents \\
\hline 1. & Primary & 19 \\
\hline 2. & Upto high school & 61 \\
\hline 3. & Upto Higher Secondary & 20 \\
\hline & Total & 100 \\
\hline
\end{tabular}

Source: Computed

The table No. 4.5, it is clearly state that 19 respondents are having Primary education, 61 respondents are having secondary education and only 20 respondents are having higher secondary education. It is found that, most of them have studied upto high school level than higher secondary and primary level. It is proved that these groups have well educated to make decision to develop women.

Table 4.6 Occupational Status wise distribution of the Respondents of the family

\begin{tabular}{|c|l|c|}
\hline Sl.No. & Occupations status & No. of Respondents \\
\hline 1. & Agriculture & 45 \\
\hline 2. & Gem cutting & 24 \\
\hline 3. & Fire wood cutting & 18 \\
\hline 4. & Driving & 5 \\
\hline 5. & Others & 8 \\
\hline & & $\mathbf{1 0 0}$ \\
\hline
\end{tabular}

Source: Computed

From the table No. 4.6 shows that the occupational status of the respondents occupations; the 45 respondents are in agriculture, 24 respondents are in Gem cutting. 18 respondents are in fire woodcutting; 5 respondents in driving and only 8 respondents are other occupation. It is found that, $(45 \%)$ of the respondents occupation in agriculture followed by gem cutting (24\%) fire wood cutting (18\%) driving $(15 \%)$ and others $(8 \%)$. It is 
found that, $(45 \%)$ of the respondents occupation in agriculture followed by gem cutting (24 $\%)$, fire wood cutting (18\%) driving (15\%) and others (8\%)

Table 4.7 Annual income of the Respondents of the family

\begin{tabular}{|c|c|c|}
\hline SI.No. & Annual income & No. of Respondents \\
\hline 1. & Below 10, 000 & 26 \\
\hline 2. & $10,000-20,000$ & 52 \\
\hline 3. & $20,000-30,000$ & 12 \\
\hline 4. & Above 30,000 & 10 \\
\hline & Total & 100 \\
\hline
\end{tabular}

Source: Computed

The table No. 4.7, shows that 26 respondents are having income of below 10,000 per annum 52 respondents are having income between Rs.10,000-20,000; 12 respondents are having income of above Rs.20, 000-30,000 and only 10 respondents are having income of above Rs.30,000 The main reason for low income is lower level of wages and also this study region is having more dry land.

Table 4.8 Annual income of the Respondents in the group

\begin{tabular}{|c|l|c|}
\hline S.No. & Income range in Rs & No. of Respondents \\
\hline 1 & Below & - \\
\hline 2 & $6001-12000$ & 38 \\
\hline 3 & $12001-18000$ & 62 \\
\hline 4 & Above $18000 \quad$ Total & $\mathbf{1 0 0}$ \\
\hline & \multicolumn{2}{|r}{} \\
\hline
\end{tabular}

Source: Computed

The Table No.4 8 indicates the earning of the respondents. The table explains that the 38 respondents are earning of Rs.6001-12000 range of income in a month and 62 respondents are earning 12001-18000. It is round that, most of the represents $(62 \%)$ are earning in the range of Rs. $12001-1800$ followed by Rs. $6001-12000$ (38\%) respectively.

\section{Testing of hypotheses}

Occupation and income per year in self Help groups

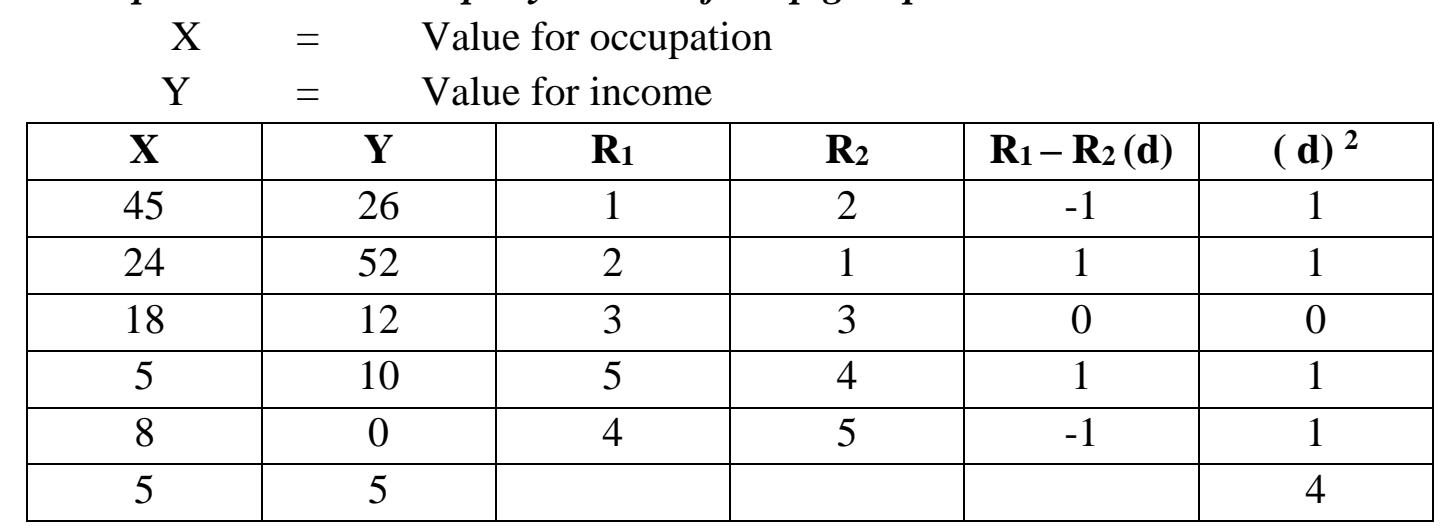




$$
\begin{aligned}
& r=1-\frac{6 \times \sum d^{2}}{n-\left(n^{2}-1\right)} \\
& =1-\frac{6 \times 4^{2}}{5\left(5^{2}-1\right)} \\
& =1-\frac{6 \times 16}{5(25-1)} \\
& =1-\frac{96}{5(24)} \\
& =1-\frac{96}{120} \\
& =1-0.8 \\
& r=0.2
\end{aligned}
$$

From the analysis the calculated value 0.2 positive correlations between occupation and income of Self - Help Groups. Therefore the hypothesis is an accepted. There is a positive correlation between occupation and income level.

\section{SUMMARY OF FINDINGS}

Gender inequality is a problem felt by Indian society. Especially in rural areas, from time immemorial. Any step towards attaining gender equality must be in the line of including and developing women entrepreneurship and thereby ensuring women empowerment. Keeping this view in mind, this study intends to evaluate the performance and problems faced by the women entrepreneurs for which the analysis of socio and economic factors of the respondents is important. Following are the significant findings. Age wise distribution of respondents, shows that the $40 \%$ of them are belongs to the age group of $26-30$ and other $30 \%$ of them belong to the category of 31-35. Out of the total respondents 50 of the them are scheduled caste.

The majority of the respondents $(85 \%)$ respondents are married and only very few of them are unmarried. The study shows that $(65 \%)$ of the respondents are from nuclear families. According to the size of the family is concern 45 respondents the families are having 3-7 members are found 20 respondents are having more than 7 members also another 35 respondents are having only less than 3 members. Studied up to high school (61\%) of them.

It is found that, (45\%) of the respondents occupation in agriculture followed by gem cutting (24\%), fire wood cutting (18\%) driving (15\%) and others ( $8 \%$ )' The 53 respondents are having income between Rs.10,000 - 20,000. It depicts that, the poverty is one of the main reasons in rural area. This is because of monsoon - failure, the study area is also a region. The majority of them below poverty line $(58 \%)$ and 42 percent of them need credit facility to fulfill their requirements. 
It is found that, majority of the members are belongs to the members group of 15-20 this member group will function dynamically because this optimum level for work. It is clearly noted that, Involvement if credit facility by the members are more (76\%) than group development (24\%) respectively. It is found that, most of the represents (62\%) are earning in the ranges of Rs.12001-18000 followed by Rs. 6001-12000 (38\%) respectively.

It is clearly stated that, majority of the respondents (46\%) are savings through banks and only very few $(5 \%)$ of the them from other type of mode. It is noticed that, most of them are spending (48\%) above Rs. 8001 in a year in more than $(22 \%),(17 \%)$ and $(13 \%)$ spending in the range of Rs.4001, 6000, below 4000 and $6001-8000$ respectively.

It is found that, most of the respondents are borrowed only from bank compare with other type of borrowing (19\%) from money lenders; (18\%) from co-operative bank, (15\%) from office respectively. It is revealed that, most of them are $(47 \%)$ spending as them family maintains followed by (36\%) as their machine, only (17\%) for their education. It is found that, the respondents are equally responded to attend the meeting weekly and monthly by 50:50 ratios. Analysis the calculated value 0.2 positive correlations between occupation and income of Self - Help Groups. Therefore the hypothesis is an accepted. There is a positive correlation between occupation and income level.

\section{CONCLUSION}

SHG undertake entrepreneurial activities at smaller level with minimum capital requirements. SHGs have the power to create a socio economic revolution in the rural areas of our country. Self help groups have proved that they could indeed bring about a change in the mindset of very conservative and traditional bound illiterate women in rural areas, self help group have made the rural women to contribute for the socio economic progress of the country. The self help groups play a major role in transforming rural economy through microfinance to improve their standard of living and fulfill their credit needs, the SHGs are new innovation in the fields of rural development to finance the rural poor.

\section{BIBLIOGRAPHY}

1. Lalitha Shivakumar N (2018) Self Help Groups" Social Welfare, Vol. 42, No. 4P.9

2. Gurumoorthy T.R (2018) "Self Help Group Empower Rural Women" Kurukshetra, Vol.15, PP-20-22.

3. Sivasubamnanian M.N.(2017) "Credit based Poverty alleviation Programme Innovative Approach” Kurushetra, Vol. 48. No. 2. P.No. 37

4. Dwaraki B.R. Kumaresen B (2016) Self Help Groups Quovadis? Social Welfare” Vol. 44, No 3. P.No. 40.

5. Patel A.R (2016) “ Rural credit system” Kurukshetra, Vol. 49 No. 4, P.17

6. Ghosh, O.K.(2015) "NGO Intervention in Poverty Alleviation" Kurukshetra Vol. 49. NO.6.P.2

7. Jaya Anand(2015) "Micro Finance in Kerala" Kurukshetra, Vol. 48, No. 11, P.16 
8. Mohanam S." (2014) Micro Credit and Empowerment of women Role of NGOs" Yojana, , Vol. 44. No. 7.P.21

9. Nagayya GD., (2013) "Micro finance for Self Help Group" Kurukshwtra, VIl. 48.No. 11, P.10

10. Preethi Chandrasekar(2014) "Mahalir Thittam upgrades SHgs" Hindu Publication, 2002, P.5

11. Puhazheendhi (2013) SHGs "Indian Journal of Agricultural Economic, Vol/ 56, No. 3, P. 450

12. Rajamohan, S. (2003) "Activities of Self Help Group in Virdhunagar District a study in Tamil Nadu Journal of co-operation, Vol. 3. NO. 6, P.IS.

13. Ramesh C and Srivastava (2003) "Development initiatives for Poorer Sections" Social welfare,. Vol.49, No. 10, P.28

14. Rarnalakshmi, C.S. ( 2003) "Empowerment through Self Help Groups" Economic and Political weeklyVol. XXXVIII, Nos 12 and 13, PO.1302

15. Sivarainakrishnan. K. (2003) Poverty all eviction through Self Help Group TNJC, Vol.3, No. 5, $P-9$

16. Sumar Krishna Kant. K. (2001) “Women's Empowerment \& Mutual Co-Operation in the Family” Social Welfare, , Vol.48, No.1, P.P.3 -4 